\title{
Market Power and Bank Liquidity Risk: Implementations of Basel III using Net Stable Funding Ratio Approach
}

\author{
Jul Aidil Fadli ${ }^{*}$, Imanuel Madea Sakti ${ }^{2}$, Sapto Jumono ${ }^{3}$ \\ 1,3 Esa Unggul University, Indonesia \\ ${ }^{2}$ Universitas Kristen Satya Wacana, Indonesia \\ *Corresponding Author: jul.fadli@esaunggul.ac.id
}

\begin{abstract}
Net Stable Funding Ratio (NSFR) published by Basel III as a new standard of bank liquidity risk management. In Indonesia, the Financial Services Authority (OJK) issued the OJK Regulation No. 50/POJK. 03/2017 concerning the obligation to fulfill the NSFR for commercial banks. The research objective is to test the influence of bank market power of assets, loans, and third-party funds toward bank's liquidity risk that measured by NSFR. The research uses a data panel from 37 commercial banks in Indonesia in the period 2018Q1-2019Q4. The hypotheses are examined by using linear regression methods with a random effect model. The result shows that the effect of market power on the risk of bank liquidity is proved. Market power will increase the NSFR, which means the higher the market power, the better management of liquidity risk. This research is expected to contribute theoretically to provide the latest literature on the application of Basel III through the NSFR approach, a current measurement for bank liquidity risk. Furthermore, this research is expected to contribute practically to banks and regulators in the formulation of policies related to market control and bank liquidity risk management. Based on the result, financial consolidation to enhance market power can be a solution to encourage bank liquidity.
\end{abstract}

Keywords: bank liquidity; market power; NSFR; risk; stability

\section{INTRODUCTION}

In carrying out their operational activities, banks face various risks, especially risks related to the bank intermediary function. The bank's business model aims to facilitate the flow of funds/capital in an economy by performing an intermediary function between two parties; depositors as surplus spending units and borrowers as deficit spending units. The bank also acts as liquidity creation which provides illiquid loans to borrowers and the same time allows depositors to withdraw funds according to their nominal value (par value) in a short time. This business model forces banks to face the liquidity risk that is considered a major threat to the management and the stability of financial institutions 
(Khan et al., 2017). This condition would be more crucial during the financial crisis period (Acharya et al., 2009).

The 2008 global financial crisis showed that strong capital did not guarantee banks to survive in crisis conditions. The inability of banks to meet liquidity risk management standards was a challenge for the banking industry at the time. Therefore, the Basel Committee (2014) published Basel III: The Net Stable Funding Ratio (NSFR), as one of the Basel Committee's main reforms to build a stronger banking industry. The application of NSFR in Basel III is a refinement of bank capital principles previously regulated in Basel II.

NSFR requires banks to maintain a stable funding profile related to asset composition and off-balance sheet activities (Basel Committee, 2014). Sustainable funding aims to reduce the potential disruptions of the bank's regular funding sources that can erode its liquidity. This condition results in the increasing risk of bank failure in meeting obligations to depositors and could also cause extensive systemic pressure. The NSFR limits the dependence on short-term funding sources encourages better funding risk management across all on-balance sheet and off-balance sheet items and promotes funding stability. Thus, the application of regulations related to NSFR is expected to strengthen the health and endurance of individual banks in facing crises. In Indonesia, the Financial Services Authority (OJK) issues OJK Regulation No. 50/POJK.03/ 2017 concerning the Obligation to Fulfill Net Stable Funding Ratio for Commercial Banks (OJK, 2017). Article 2 Paragraph 4 of OJK Regulation No. 50/POJK.03/2017 states that compliance with the NSFR is set to be at least 100 percent. This regulation applies to Commercial Banks Business Activities (BUKU) 4 and 3 and foreign banks as stated in Article 4.

One factor that influences the risk level of banks is competition in the industry. Pricillia (2015) found a positive effect of market concentration on market risk and loan risk. A more concentrated market (low level of market competition) will encourage banks to take higher risks, such as applying high interest rates to maintain profits and market power. However, this action also leads to loan defaults and increases loan risk exposure.

Analysis of the competition level in the industry using market power measurement has become the main focus in the research of industrial economics, including analysis of the level of competition in the banking industry. Clark et al. (2018) examined the effect of bank competition on bank stability by proposing two dominant theories. The first theory, competition-fragility theory (or concentration-stability), states a negative relationship between market power and risk-taking, which is a measure of bank stability. Small market competition causes a large amount of bank power in the market to increase the bank's charter value, ease of accessing information, and obtain an economy of scope and economy of scale in its operations (Wu et al., 2019). The second theory, competition stability theory (or concentration-fragility) states that the competitive banking sector can reduce the power of banks in the market, bank interest rates, and the risk of default on loans to improve the bank's risk profile (Wu et al., 2019).

The level of market competition also represents the level of market concentration so that the level of market competition, concentration, and power are interconnected. The measurement of the level of competition is divided into two approaches. First, a structural approach that uses market structure information, which are market share, number of companies, barriers to entry, and market concentration. Second, the non-structural approach does not use market structure information but instead uses the competition itself. 
These approaches are called the Lerner index, the H-statistic/Panzar-Rosse method, and the Bresnahan Model (Yuanita, 2019).

The concentration ratio is the most used approach to measure competition, which influences bank performance in the structural approach. The more concentrated the market, the greater the company (bank) ability to raise prices above marginal costs. It means that the obtained market power will be higher to get the profit. The high market power indicates a low level of competition. Competition in the banking market could increase bank risk. This was triggered by a strategy that increases deposit rates offered by banks as an attraction for depositors. Instead, this strategy makes the bank run a higher risk. In other words, the greater the market power, the lower the risk borne by the bank. Meanwhile, Boyd \& De Nicoló (2005) states that competition in the loan market causes banks to offer lower interest rates, reducing the risk of default from borrowers. Furthermore, the flexibility of banks to select prospective borrowers has an impact on reducing the risk of default.

One of the efforts to create a stable banking sector is through the implementation of the NSFR. However, less banking literature in Indonesia discusses the impact of competition on managing bank liquidity risk, especially related to the NSFR approach as Basel III implementation. Indonesia is the sixth-largest economy in the Asia Pacific region, with a US \$1,042 trillion GDP, and is the fourth most populous country in the world with an estimated population of 267.66 million (World Bank, 2020). Meanwhile, Indonesia's financial sector is dominated by banking, representing $77 \%$ of the total financial system assets (Bank Indonesia, 2019).

As an intermediary institution, the role of banks is vital in supporting the process of national economic development through the real sector and investment (Fahrial, 2018). Banks collect third-party funds and distribute these funds in the form of loans to society. The intermediation process would experience obstacles when the distortion in the function of the banking industry resulting in inefficient performance. With these obstacles, the existing funds cannot be used to finance the business growth and development projects.

Furthermore, banks are the main source of financing in most developing countries (Čihák et al., 2013). It indicates that the impact of bank instability will be worse in developing countries compared to countries that do not really depend on banks (Kroszner et al., 2007). Therefore, investigating the effect of market power based on asset, loan, and third-party fund on bank's risk is critical to support financial stability and economic growth in developing countries.

These arguments show that no clear consensus has been reached in the literature regarding the relationship between market power and bank risk, especially on bank liquidity risk in developing countries. To fill the gap in the literatures, this research aims to analyze the effect of market power of asset, loan, and third-party fund on bank liquidity risk in the Indonesian banking sector using the NSFR as current measurement for bank liquidity risk.

This research is expected to contribute practically to banking players in implementing market control strategies and liquidity risk management. For regulators, this research is expected to be the basis for the formulation of policies to maintain the banking industry's stability. Hopefully, this research could increase the empirical evidence reported 
in the banking literature in Indonesia about bank market power and bank liquidity risk, especially through the implementation of Basel III with the NSFR approach.

The paper proceeds as follows. Section1 Introduction provides a background of the study. Section 2 explains the Hypotheses Development underlying our estimation of bank liquidity risk and bank market power. In Section 3, we explain the Method, Data, and Analysis. Then in section 4, we provide results and discussion, then Conclusion, Limitations, and Suggestions in section 5.

\section{HYPOTHESES DEVELOPMENT}

\section{Bank Liquidity}

As an intermediary and financial service provider, banks face various risks in their operations. Saunders \& Cornett (2017) suggested several risks faced by banks, including interest rates, market risk, loan risk, off-balance-sheet risk, foreign exchange risk, country risk or government risk, technology risk, operational risk, liquidity risk, and risk insolvency.

Dahir et al. (2018) define liquidity risk as an inability to finance cash outflows at a certain point in time. Bank has concerns about liquidity risk when depositors withdraw funds that exceed the funds that is available in the bank. This condition happens because customer's withdrawals are random and unpredictable. The failure of the bank to return customer funds can trigger a "bank run," which has a systemic impact on the economy. Liquidity can be generated on both sides of the bank's balance sheet (Berger \& Bouwman, 2009). Banks not only pay obligations that are due by using liquid assets they own, but also banks can convert illiquid assets into liquid assets by doing fire sale. Thus, liquidity creation can be done on the balance sheet side of the assets.

The Basel Committee (2014) formulated Basel III, which contains two new standards related to bank funding which are Liquidity Coverage Ratio (LCR) and Net Stable Funding Ratio (NSFR). LCR is a comparison of High-Quality Liquid Asset (HQLA) with total cash outflows (Net Cash Outflow) for the next thirty days in the financial pressures scenario. Meanwhile, NSFR is a comparison between Available Stable Funding (ASF) as a number of stable liabilities and equity over a one-year period, with Required Stable Funding (RSF) as a number of assets and administrative account transactions that need to be funded. NSFR aims to reduce the risk of funding liquidity arising from maturity mismatches between bank assets and liabilities (Ly et al., 2017). NSFR is defined by King (2013) as a comparison between the amount of available stable funds (ASF) divided by the number of stable funds needed (RSF). If the RSF is higher than the ASF, the bank is exposed to the risk of selling assets at fire sales prices to pay liability claims on demand. The main idea presented at the NSRF is that banks use stable sources to fund their business and reduce dependence on short-term funding sources.

\section{Market Power}

Gutiérrez de Rozas (2011) defines market power as individual companies' behavior in managing pricing strategies, while competition is more related to the interaction of market members or more aggregate. Some previous studies have revealed the importance of competition in the financial sector. First, competition can increase access to financial services by households and companies (Beck et al., 2004). Second, competition can create efficient functions in the banking sector (Claessens \& Laeven 2005). Third, competition can create stability in the financial system (Boyd et al., 2004). Fourth, competition fosters 
efficient financial intermediary management (Berger \& Hannan, 1989). Fifth, competition can maintain interbank market interest rates, increasing the transmission of monetary policy (Van Leuvensteijn et al., 2008). Lastly, competition drives industrial progress and economic growth (Allen \& Gale, 2004).

Market power (also known as monopoly power) is companies' ability to set prices above marginal prices s or additional costs in an imperfect competition market (Wang et al., 2014). The concept of market power also applies to the banking industry with the characteristics of intervention and strict administration in its operations. Thus, it can be concluded that market power is the ability of economic entities to control prices in the market. The higher the company's market power, the more competitive and the higher the value that the company has. Furthermore, the greater the market power, the stronger the monopoly position of a company, and the less competition it faces, the easier it is for the company to obtain larger profits (Wang et al., 2014).

\section{The Effect of Market Power on Bank Liquidity}

Theoretical and empirical evidence in the banking literature suggest arguments which support the competition-stability theory through "too big to fail" point of view centered on the Structure-Conduct-Performance paradigm. In this point of view, several large banks can influence financial authorities to not let banks fail, which in turn increases the risk-taking behavior's incentives for banks. This is due to the systemic impact of the failure that these large banks created, which further could threaten the stability of the entire financial system (Clark et al., 2018).

The competition-stability theory is built on the risk-shifting paradigm. By seeing from both the loan and savings market, this theory mentioned that banks with significant market power tend to charge high-interest rates. This behavior leads to the difficulty of customers to pay debts due to the emergence of moral hazard and adverse selection (Clark et al., 2018). Furthermore, an increase in defaulted loans in bank portfolios will occur and disrupt the financial system (Boyd \& De Nicoló, 2005). In this model, higher interest rates result from the reduced competition in the loan market. As such, this encourages borrowers to adopt riskier projects. Sequentially, risky projects tend to lead to higher default rates and result in an increase in bank default loans. This condition increases the chances of bankruptcy and bank instability. With higher interest rates, opportunities for adverse selection and moral hazard will increase because the borrowers prefer risk with high-profit expectations. Thus, the competition results in a lower loan rates to borrowers (moral hazard and adverse selection decline) leading to less risky project financing. This condition reduces the risk of customer default, thereby reducing the risk of bank failure.

Research by Nguyen et al. (2017) in the banking industry in 101 countries showed that market power can have both of positive and negative effect on bank liquidity risk. This situation can reduce the dependency of the banks on asset liquidity associated with high opportunity costs, adverse selection, and the emergence of moral hazard. Conversely, referring to Agency Theory (Jensen \& Meckling, 1976), tighter competition (small market power) in the third-party funds market tends to make banks more motivated to take high risks. When banks pay higher interest rates for third party funds, banks face higher deposit interest payments, which further aggravates the moral hazard of the bank. 


\section{Market Power of Assets and Liquidity Risk}

Banks with significant market power in asset impose high-interest rates despite low borrower risk profiles, so customers are reluctant/refuse to become bank partners (Khan et al., 2017). It can trigger a high non-performing loan at the bank. This condition is consistent with the competition-fragile theory which states that interbank competition increases instability in the banking loan system and operational risk probability. Thus, it can be concluded that a greater market power will keep the bank away from the risk of instability and vice versa. Based on this review, hypotheses that developed is shown as follow:

\section{$H_{1 a}$ : Market power of the asset affects bank liquidity risk}

\section{Market Power of Loan and Liquidity Risk}

Research by Boyd \& De Nicoló (2005) showed that competition in the loan market makes banks offer lower interest rates. It encourages a reduction in the cost of loan to be paid by customers, thereby it will also reduce the risk of default from borrowers to the banks. Furthermore, banks can be more selective in choosing customers who have the least default risk by offering lower interest rates. Meanwhile, the research of Nguyen et al. (2017) towards banks in 101 countries shows that banks that can control the market are proven to have better liquidity capabilities. Based on this review, hypotheses that developed is shown as follow:

\section{$H_{1 b:}$ Market power of the loans affects the bank liquidity risk}

\section{Market Power of Third-Party Fund and Liquidity Risk}

Hellmann et al. (2000) shows that competition in the banking market encourages banks to offer higher deposit rates to attract depositors. This strategy requires banks to obtain greater profits to keep promises to depositors. In the end, it forces banks to take higher risks. In other words, a higher market concentration leads to a more stable banking system. It shows that banks which can dominate the deposit market tend to operate in more stable way tend to be more stable. Based on this review, hypotheses that developed is shown as follow:

\section{$\mathrm{H}_{1 c}$ : Market power of the third-party funds affects bank liquidity risk}

Based on hypotheses that developed, framework of the research as following in the Figure 1.

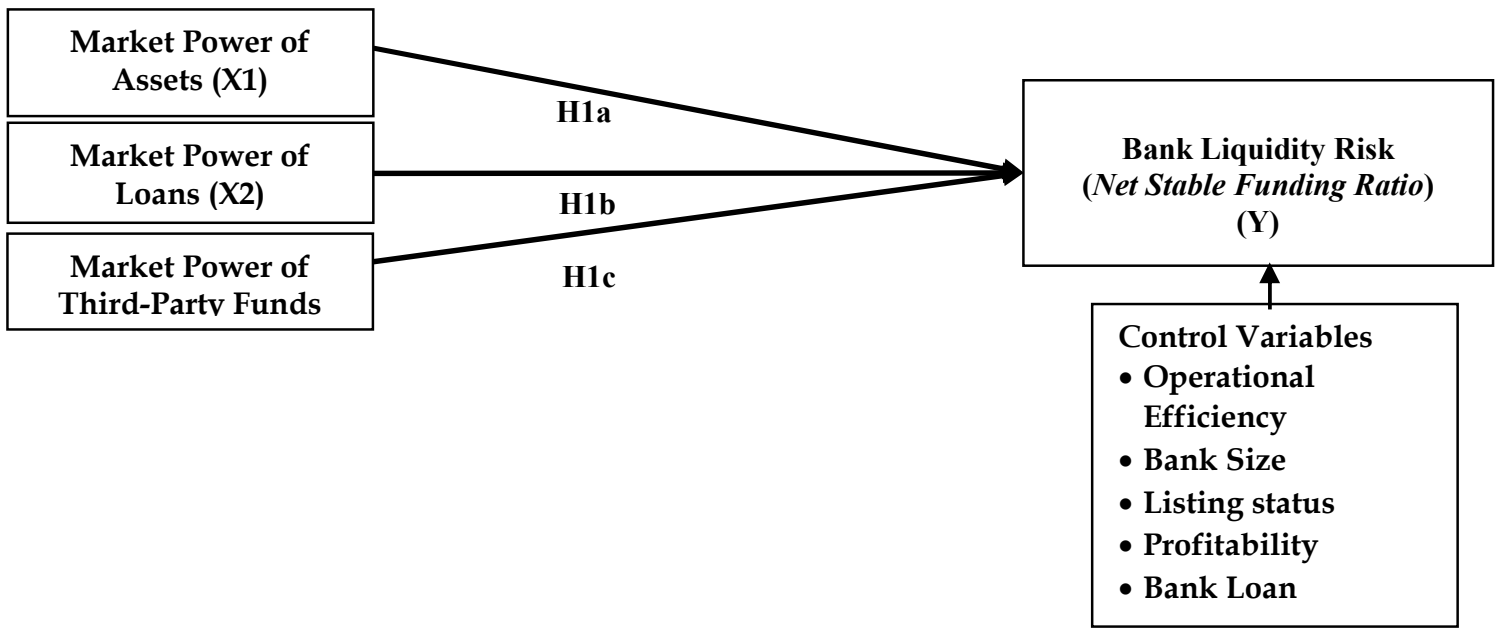

Figure 1. Research Framework 


\section{METHOD, DATA, AND ANALYSIS}

The object of this research is commercial banks in Indonesia with an observation period during the first quarter of 2018 until the fourth quarter of 20191. The sampling method uses the purposive sampling method with the criteria shown in Table 1. The data used is quarterly panel data (cross-sectional and time series) obtained from the bank's quarterly financial statements and Indonesian Banking Statistics published by the Indonesian Financial Services Authority (OJK). Based on the criteria in Table 1, the final sample of 37 banks was selected with a total of 296 observations.

Table 1. Sample Selection Criteria

\begin{tabular}{lc}
\hline Criteria & Amount \\
\hline Commercial Banks in Indonesia in 2018-2019 & 110 \\
Sharia Commercial Bank & $(14)$ \\
Does not publish NSFR data & $(59)$ \\
\hline Number of final samples & 37 \\
Period of observation (quarter) & 8 \\
Number of observations & 296
\end{tabular}

Secondary data testing in this research uses panel data regression. The following are mathematical equations (1) and equations (2).

$$
\begin{aligned}
& \text { NSFR }_{i t}=\alpha_{i t}+\beta_{1} \text { MSasset }_{i t}+\beta_{2} \text { MSloan }_{i t}+\beta_{3} \text { MSdep }_{i t}+\beta_{4} \text { Controls }_{i t}+\varepsilon_{i t}(1) \\
& N S F R_{i t}=\alpha_{i t}+\beta_{1} D_{-} C R 4_{i t}+\beta_{2} \text { Controls }_{i t}+\varepsilon_{i t} \\
& a, \beta=\text { Constants } \\
& \sum \text { Control }=\text { EFF, SIZE, DLISTED, ROE, LAR } \\
& \text { it } \quad=\text { cross section and time series } \\
& \varepsilon \quad=\text { error term }
\end{aligned}
$$

Equation (1) is used to examine the effect of market power on bank liquidity risk. While equation (2) is used to perform robustness tests, using the D_CR4 variable as an independent variable replacing the MS variable. The D_CR_4 variable is a dummy variable for banks that are members of the four largest banks in each period both in terms of assets, loans, and third-party funds. Banks that are members of the four largest banks are marked 1 , and banks that are not affiliated with the four largest banks are marked 0 .

\footnotetext{
${ }^{1}$ As stated by OJK Regulation No. 50 / POJK. 03/2017 concerning the obligation to fulfill the NSFR for commercial banks in article 15 paragraph 1, that the NSFR publication obligations come into effect in March 2018 reporting. In this study, the most recent period data used is Q4 2019 to avoid the effects of Covid-19 which have impact on the economy generally and bank risks especially.
} 
The variables and measurements used in this research are shown in Table 2:

Table 2. Variable and Measurement

\begin{tabular}{|c|c|c|}
\hline Variable & Proxy & Indicator \\
\hline \multicolumn{3}{|l|}{ A. Dependent Var. $(Y)$} \\
\hline \multirow[t]{2}{*}{ Bank Liquidity Risk } & \multirow[t]{2}{*}{ NSFR } & Available amount of stable funding \\
\hline & & $\overline{\text { Required amount of stable funding }}$ \\
\hline \multicolumn{3}{|l|}{ B. Independent Var. (X) } \\
\hline \multirow[t]{2}{*}{ Market Power of Asset } & \multirow{2}{*}{$\mathrm{MS}_{\text {asset }}$} & Total asset of the bank \\
\hline & & $\overline{\text { Total asset of the industry }}$ \\
\hline \multirow[t]{2}{*}{ Market Power of Loan } & \multirow[t]{2}{*}{$\mathrm{MS}_{\text {loan }}$} & Total loan of the bank \\
\hline & & Total loan of the industry \\
\hline \multirow{2}{*}{$\begin{array}{l}\text { Market Power of } \\
\text { Third Party Fund }\end{array}$} & \multirow[t]{2}{*}{$\mathrm{MS}_{\text {dep }}$} & Total third party fund of the bank \\
\hline & & Total third party fund of the industry \\
\hline Market Concentration & D_CR4 & $\begin{array}{l}1=\text { the four biggest banks, } 0=\text { non the four } \\
\text { largest banks }\end{array}$ \\
\hline \multicolumn{3}{|l|}{ C. Control Var. } \\
\hline \multirow[t]{2}{*}{ Operational Efficiency } & \multirow[t]{2}{*}{ EFF } & Operating costs \\
\hline & & $\overline{\text { Operating income }}$ \\
\hline Bank Size & SIZE & $\ln ($ Total assets \\
\hline Listing status & D_LISTED & $1=$ listed, $0=$ not listed \\
\hline Profitability & ROE & Net profit \\
\hline \multirow{2}{*}{ Bank Loan } & \multirow{2}{*}{ LAR } & $\begin{array}{l}\text { Total Equity } \\
\text { Total loans }\end{array}$ \\
\hline & & $\overline{\text { Total assets }}$ \\
\hline
\end{tabular}

Based on research by Jumono et al. (2017), the market competition that occurs can be classified as follows:

a. $\mathrm{CR} 4=0$, then the market in the industry is classified as a perfectly competitive market

b. $0<\mathrm{CR} 4<40$, the market in the industry is classified as effective competition or monopolistic competition

c. $40 \leq \mathrm{CR} 4 \leq 60$ : the market in the industry is classified as loose Oligopoly or monopolistic competition.

d. $60 \leq$ CR4: then the market in the industry is classified as a tight Oligopoly or dominant company with edge competitors

e. $90 \leq \mathrm{CR} 4$ : the market in the industry is classified as an effective Monopoly or a dominant company with a competitive edge. 


\section{RESULTS}

\section{Descriptive Statistics Test}

The descriptive statistical test results are shown in Table 3. The mean value of the bank liquidity risk variable measured by NSFR is 128.03 percent, with the minimum and maximum values respectively 88.08 percent and 237.21 percent. These statistics indicate that on average the banks sampled in this research have met the NSFR threshold of 100 percent, although there are some banks that are still unable to meet the threshold ratio. The mean values of market power variables measured by market share of assets ( $\mathrm{MS}_{\mathrm{ASSET}}$ ), loans (MS LOAN), and third party funds (MS $_{\text {DEP }}$ ) are 2.21 percent, 1.50 percent, and 1.92 percent respectively, with a maximum value of 15.68. percent, 10.85 percent, and 14.17 percent. Descriptive statistical results from the control variables EFF, SIZE, ROE, and LAR, then D_CR4 for robustness tests can be seen further in Table 3 .

Tabel 3. Descriptive Statistics Test

\begin{tabular}{cccccc}
\hline Variable & Obs & Mean & Std. Dev. & Min & Max \\
\hline NSFR & 280 & 128.031 & 27.037 & 88.08 & 237.21 \\
MS $_{\text {asset }}$ & 282 & 2.214 & 3.676 & 0.015 & 15.685 \\
MS loan & 282 & 1.506 & 2.531 & 0.008 & 10.851 \\
MS dep & 282 & 1.922 & 3.388 & 0.001 & 14.179 \\
D_CR4 & 296 & 0.108 & 0.311 & 0 & 1 \\
EFF & 245 & 86.820 & 15.066 & 52.540 & 163.220 \\
SIZE & 282 & 17.815 & 1.665 & 13.912 & 21.018 \\
D_LISTED & 296 & 0.513 & 0.500 & 0 & 1 \\
ROE & 281 & 6.145 & 9.440 & -65.131 & 53.471 \\
LAR & 282 & 65.193 & 9.679 & 38.705 & 84.565 \\
\hline
\end{tabular}

Source: Data processed (2020)

Table 4. Four Largest Bank Concentration

\begin{tabular}{|c|c|c|c|c|}
\hline Periods & 4 Largest Bank & $\mathrm{CR}_{\text {ASET }}$ & $\mathrm{CR}_{\text {LOAN }}$ & CR4 $4_{\text {DEP }}$ \\
\hline $2018 \mathrm{q} 1$ & BRI, MANDIRI, BCA, BNI & 46.631 & 31.418 & 42.966 \\
\hline $2018 \mathrm{q} 2$ & BRI, MANDIRI, BCA, BNI & 47.342 & 32.051 & 43.180 \\
\hline $2018 \mathrm{q} 3$ & BRI, MANDIRI, BCA, BNI & 47.440 & 32.257 & 43.885 \\
\hline $2018 \mathrm{q} 4$ & BRI, MANDIRI, BCA, BNI & 47.525 & 32.582 & 43.432 \\
\hline 2019q1 & BRI, MANDIRI, BCA, BNI & 47.150 & 32.463 & 43.488 \\
\hline $2019 q 2$ & BRI, MANDIRI, BCA, BNI & 47.642 & 33.002 & 43.416 \\
\hline $2019 q 3$ & BRI, MANDIRI, BCA, BNI & 47.845 & 33.047 & 44.200 \\
\hline $2019 q 4$ & BRI, MANDIRI, BCA, BNI & 48.477 & 33.365 & 44.670 \\
\hline
\end{tabular}

Source: Data processed (2020) 
Meanwhile, Table 4 shows the banks in the category of the four largest banks along with a concentration ratio (CR4) value during the observation period 2018Q1 to 2019Q4. Banks with the largest share in a sequence are BRI, MANDIRI, BCA, and BNI. CR4 values ranged from 46.63-48.47 percent (CR4 $4_{\text {ASSET }}$ ), 31.41-33.36 percent (CR4 $4_{\text {LOAN }}$ ), and 42.96-44.67 percent (CR4 $\left.4_{\mathrm{DEP}}\right)$. The CR4 value in this research shows that monopolistic competition has formed in the banking market in Indonesia.

\section{Selecting Estimated Models}

Before conducting a hypothesis test, this research conducted several tests to select the best estimation model, Pooled Least Square (PLS), Fixed Effect Model (FEM), or Random Effect Model (REM). A summary of the results of the estimation model selection test is shown in Table 5 as follows:

Table 5. Test results for estimation model selection

\begin{tabular}{|c|c|c|c|}
\hline \multicolumn{2}{|l|}{ Uji Chow (PLS vs FEM) } & \multirow{2}{*}{$\begin{array}{l}\text { Prob > F } \\
0.000\end{array}$} & \multirow{2}{*}{$\begin{array}{l}\text { Decision } \\
\text { choose FEM }\end{array}$} \\
\hline Model 1: & $\mathrm{MS}_{\mathrm{ASSET}}$ & & \\
\hline Model 2: & $\mathrm{MS}_{\text {LOAN }}$ & 0.000 & choose FEM \\
\hline Model 3: & $\mathrm{MS}_{\mathrm{DEP}}$ & 0.000 & choose FEM \\
\hline Model 4: & D_CR4 & 0.000 & choose FEM \\
\hline \multicolumn{2}{|c|}{ Uji Breusch Pagan LM (PLS vs RE) } & Prob > chi2 & Decision \\
\hline Model 1: & $\mathrm{MS}_{\mathrm{ASSET}}$ & 0.000 & choose REM \\
\hline Model 2: & $\mathrm{MS}_{\text {LOAN }}$ & 0.000 & choose REM \\
\hline Model 3: & $\mathrm{MS}_{\mathrm{DEP}}$ & 0.000 & choose REM \\
\hline Model 4: & D_CR4 & 0.000 & choose REM \\
\hline \multicolumn{2}{|c|}{ Uji Hausman (FEM vs REM) } & Prob > chi2 & Decision \\
\hline Model 1: & $\mathrm{MS}_{\mathrm{ASSET}}$ & 0.1356 & choose REM \\
\hline Model 2: & $\mathrm{MS}_{\mathrm{LOAN}}$ & 0.1760 & choose REM \\
\hline Model 3: & $\mathrm{MS}_{\mathrm{DEP}}$ & 0.1155 & choose REM \\
\hline Model 4: & D_CR4 & 0.2232 & choose REM \\
\hline
\end{tabular}

Source: Data processed (2020)

The results show that the best estimation model is REM, so no heteroscedasticity test is needed because REM already uses Generalized Least Squares (GLS) in its estimation. To overcome the BLUE problem, a robust standard error option will be added in each estimation model.

\section{Correlation Test}

The independent variable of market power which is measured using market share in assets, loans, third party funds, and market concentration is thought to have a relationship between variables resulting in multicollinearity problems. For this reason, a correlation test was carried out using Partial Correlation in Table 6 and the multicollinearity test for Variance Inflation Factor (VIF) in Table 7. 
Table 6. Correlation Test

\begin{tabular}{|c|c|c|c|c|c|c|c|c|c|}
\hline & MS $_{\text {ASET }}$ & MS $_{\text {LOAN }}$ & $\mathbf{M S}_{\mathrm{DEP}}$ & D_CR4 & EFF & SIZE & D_LISTED & ROE & LAR \\
\hline $\mathrm{MS}_{\mathrm{ASET}}$ & 1 & & & & & & & & \\
\hline $\mathrm{MS}_{\text {LOAN }}$ & 0.9988 & 1 & & & & & & & \\
\hline $\mathrm{MS}_{\mathrm{DEP}}$ & 0.9983 & 0.9983 & 1 & & & & & & \\
\hline D_CR4 & 0.9390 & 0.9373 & 0.9445 & 1 & & & & & \\
\hline EFF & -0.4387 & -0.4337 & -0.421 & -0.3875 & 1 & & & & \\
\hline SIZE & 0.7452 & 0.7394 & 0.7272 & 0.5869 & -0.4479 & 1 & & & \\
\hline D_LISTED & 0.4670 & 0.4634 & 0.4577 & 0.3391 & -0.3183 & 0.5867 & 1 & & \\
\hline $\mathrm{ROE}$ & 0.5878 & 0.5884 & 0.5820 & 0.4951 & -0.6545 & 0.5480 & 0.3261 & 1 & \\
\hline LAR & 0.0513 & 0.0753 & 0.0642 & 0.0477 & 0.0277 & 0.0279 & 0.0300 & -0.0225 & 1 \\
\hline
\end{tabular}

Source: Data processed (2020)

The results in Table 6 show the correlation coefficient between MS and D_CR4 in the range of 0.93 to 0.99 (in bold) or greater than 0.75 or 0.80 , this indicates that there is a multicollinearity problem. Furthermore, the results of the multicollinearity test in Table 7 show that the mean VIF is greater than 10.00 , thus indicating a multicollinearity problem.

Table 7. Multicollinearity Test

Mean VIF Decision

\begin{tabular}{llll}
\hline Model 1: & MS $_{\text {ASSET }}$ & 36.87 & there is a multicollinearity problem \\
Model 2: & MS $_{\text {LOAN }}$ & 36.16 & there is a multicollinearity problem \\
Model 3: & MS & 35.66 & there is a multicollinearity problem \\
Model 4: & D_CR4 & 32.34 & there is a multicollinearity problem
\end{tabular}

Source: Data processed (2020)

Based on the two test results, this research will discuss these four measures in separate models. In addition, this research will add a strong standard error in each regression to overcome the classical agreement.

\section{Hypothesis Testing}

The results of the regression test with Random Effect Model are shown in Table 8: 
Table 8. Random Effect Model Regression Test

\begin{tabular}{|c|c|c|c|c|}
\hline $\begin{array}{l}\text { Dependent: } \\
\text { NSFR }\end{array}$ & (1) & (2) & (3) & (4) \\
\hline \multirow[t]{2}{*}{$\mathrm{MS}_{\text {ASSET }}$} & $3.4513^{* *}$ & & & \\
\hline & $(0.044)$ & & & \\
\hline \multirow[t]{2}{*}{ MS $_{\text {LOAN }}$} & & $5.1038^{* *}$ & & \\
\hline & & $(0.042)$ & & \\
\hline \multirow[t]{2}{*}{$\mathrm{MS}_{\mathrm{DEP}}$} & & & $3.5962 * *$ & \\
\hline & & & $(0.034)$ & \\
\hline \multirow[t]{2}{*}{ D_CR4 } & & & & $32.0461^{* *}$ \\
\hline & & & & $(0.012)$ \\
\hline \multirow[t]{2}{*}{ EFF } & 0.1374 & 0.1300 & 0.1296 & 0.1396 \\
\hline & $(0.583)$ & $(0.605)$ & $(0.605)$ & $(0.578\}$ \\
\hline \multirow[t]{2}{*}{ SIZE } & $-8.9016^{*}$ & $-8.9585^{*}$ & -8.4604 & -6.9162 \\
\hline & $(0.099)$ & $(0.098)$ & $(0.100)$ & $(0.123)$ \\
\hline \multirow[t]{2}{*}{ D_LISTED } & -1.5575 & -1.5531 & -1.6016 & -0.2631 \\
\hline & $(0.872)$ & $(0.72)$ & $(0.868)$ & $(0.979)$ \\
\hline \multirow[t]{2}{*}{$\mathrm{ROE}$} & -0.0061 & -0.0238 & -0.0141 & -0.0052 \\
\hline & $(0.983)$ & $(0.936)$ & $(0.962)$ & $(0.986)$ \\
\hline \multirow[t]{2}{*}{ LAR } & $-0.7841^{*}$ & $-0.8197^{*}$ & $-0.7875^{*}$ & $-0.7725^{*}$ \\
\hline & $(0.087)$ & $(0.078)$ & $(0.086)$ & $(0.091)$ \\
\hline \multirow[t]{2}{*}{ Constanta } & $319.9473^{* * *}$ & $324.0589^{* * *}$ & $313.7657^{\star \star *}$ & $287.3263^{* * *}$ \\
\hline & $(0.004)$ & $(0.004)$ & $(0.003)$ & $(0.003)$ \\
\hline Obs. & 240 & 240 & 240 & 240 \\
\hline Dummy time & YES & YES & YES & YES \\
\hline R-sq & 0.2344 & 0.2397 & 0.2387 & 0.2309 \\
\hline F (Prob > chi2) & 0.0297 & 0.0381 & 0.0242 & 0.0047 \\
\hline
\end{tabular}

Note: Numbers in brackets are $p$ values. ${ }^{* * *} \mathrm{p}<0.01$; ${ }^{* *} \mathrm{p}<0.05 ;{ }^{*} \mathrm{p}<0.10$

Source: Data processed (2020)

In general, the effect of market power variables as measured by market share based on assets, loans, and deposits showed consistent results, which were significantly positive at the $a=5 \%$ level. The coefficients of the market share are 3.4513 (MS ASSET $), 5.1038$ $\left(\mathrm{MS}_{\mathrm{LOAN}}\right)$, and $3.5962\left(\mathrm{MS}_{\mathrm{DEP}}\right)$. These results indicate that large market power will increase the bank's NSFR, which means that the ability to manage bank liquidity risk is better. It also indicates that banks which has more power tend to be able to maintain their liquidity. These results are consistent with the OECD (2011) that there is a linear relationship between 
market power and liquidity, which is supported by Nguyen et al. (2017) who found that banks with large market power have better liquidity capabilities.

Other results show that EFF, D_LISTED, and ROE were not proven to affect NSFR. SIZE was found to have a significant negative effect on the level of $\alpha=10 \%$ in models 1 and 2 , whereas in models 3 and 4 only negative effects were found but not significant. This result shows that a large bank size may not necessarily improve a bank's ability to manage liquidity risk, instead a bank with a large size is found to have a lower liquidity risk management capability.

Furthermore, LAR consistently has a significant negative effect on NSFR at $\alpha=10 \%$. This result indicates that the smaller the ratio of loans to total assets owned by banks, the better the ability to manage bank liquidity risk. On the contrary, the higher the LAR the higher also the risk of bank liquidity.

Finally, the value of R-squared in models 1-3 is around 23.44 to 23.97 percent which shows that the ability of the independent variables in the research model in explaining the dependent variable is relatively small, so there are still other variables that need to be included in the research model to be able to explain the dependent variable $r$ better. However, in overall, the results of this research prove that market power influence bank liquidity risk which means the hypotheses $\mathrm{H} 1 \mathrm{a}, \mathrm{H} 1 \mathrm{~b}$, and $\mathrm{H} 1 \mathrm{c}$ are accepted.

\section{Robustness Test}

Robustness tests are carried out by replacing the size of market power with a market concentration dummy variable (D_CR4) to see the effect of the four largest banks in the market on bank liquidity risk. The four largest banks in the assets, loans, and third party funds markets are the same bank (Table 4) so that D_CR4 testing is only done once. The robustness test results are shown in Table 8 of model 4 . The robustness test results are consistent with the main tests showing that there is a significant positive effect of D_CR4 on NSFR at $\alpha=5 \%$ with a market concentration coefficient of 32.0461 and LAR also found to have a significant negative effect on NSFR at $\alpha=10 \%$. Thus, these results confirmed the primary test of this research that Banks with significant market power tend to have better liquidity risk management. In this case, the banks which are included as the four largest banks in Indonesia are proven to have a better liquidity compared to the other banks.

\section{DISCUSSION}

This research aims to examine the effect of market power on bank liquidity risk using Net Stable Funding Ratio (NSFR) as Basel III implementation. The results support the hypothesis that market power has a positive effect on bank liquidity risk. It means that the greater the banks' market power, either in terms of assets, loans, or third party funds, the better the bank liquidity risk management. This result is strengthened by the robustness test using dummy CR4 which shows that the four largest banks have better liquidity risk management than other banks. Also, the types of banking markets in Indonesia show a monopolistic market competition based on CR4 calculations $(0<\mathrm{CR} 4<40)$.

Bank with significant market power position and has strong access to funding and credit will increases its access to liquidity both in retail and wholesale (Cocco et al., 2009). This situation can reduce the dependency of the banks on asset liquidity associated with high opportunity costs, adverse selection, and the emergence of moral hazard. Furthermore, banks can be more selective in choosing customers who have the least default risk by offering lower interest rates. Meanwhile, the research of Nguyen et al. (2017) 
towards banks in 101 countries shows that banks that can control the market are proven to have better liquidity capabilities.

Thus, it can be concluded that market power as the ability of economic entities to control prices in the market. The higher the bank's market power, the more competitive and the higher the value that bank has. Furthermore, greater bank market power lead to stronger monopoly position of a bank in the market. Then, the less competition it faces, lead to larger benefit obtained by the bank.

\section{CONCLUSION, LIMITATIONS, AND SUGGESTIONS}

\section{Conclusion}

These results confirmed the hypotheses that banks with significant market power tend to have better liquidity risk management measured by NSFR. These results are consistent with the OECD (2011) and Nguyen et al. (2017 that there is a linear relationship between market power and liquidity. This research is expected to contribute theoretically to provide the latest literature on the application of Basel III through the NSFR approach, current measurement for bank liquidity risk. Furthermore, this research is expected to contribute practically to banks and regulators in the formulation of policies related to market control and bank liquidity risk management. Financial consolidation to enhance market power can be solution to encourage bank liquidity.

\section{Limitation and suggestions}

This research only uses a measure of market power based on market share and does not involve other bank-specific factors as well as macroeconomic factors. Future studies are expected to be able to use other measures of market power such as the Herfindahl Hirschman Index, Lerner index, Panzar-Rosse H-statistics Yuanita (2019) as well as other bank-specific factors such as capital ratios, interest income, and bank ownership, as well as macroeconomic factors such as inflation and gross domestic product (GDP) as a control variable.

\section{REFERENCES}

Acharya, V. V., Shin, H. S., \& Yorulmazer, T. (2009). Endogenous choice of bank liquidity: The role of fire sales. SSRN Electronic Journal. https:/ / doi.org/10.2139/ssrn.1517693

Allen, F., \& Gale, D. (2004). Competition and financial stability. In Journal of Money, Loan and Banking (Vol. 36, pp. 453-480). Ohio State University Press. https:// doi.org/10.2307/3838946

Bank Indonesia. (2019). Statistik sistem keuangan Indonesia bulan Desember 2019. https://www.bi.go.id/id/statistik/sski/Pages/SSKI_Desember_2019.aspx

Basel Committee. (2014). Basel Committee on banking supervision Basel III: The net stable funding ratio. October.

Beck, T., Demirguc-Kunt, A., \& Maksimovic, V. (2004). Bank competition and access to finance: International evidence. Journal of Money, Loan, and Banking, 36(3b), 627-648. https:/ / doi.org/10.1353/mcb.2004.0039

Berger, A. N., \& Bouwman, C. H. S. (2009). Bank liquidity creation. Review of Financial Studies, 22(9), 3779-3837. https://doi.org/10.1093/rfs/hhn104

Berger, A. N., \& Hannan, T. H. (1989). The price-concentration relationship in banking. The 
Review of Economics and Statistics, 71(2), 291. https:// doi.org/10.2307/1926975

Boyd, J. H., \& De Nicoló, G. (2005). The theory of bank risk taking and competition revisited. Journal of Finance, 60(3), 1329-1343. https://doi.org/10.1111/j.15406261.2005.00763.x

Boyd, J. H., De Nicolo, G., \& Smith, B. D. (2004). Crises in competitive versus monopolistic banking systems. Journal of Money, Loan and Banking, 36(3), 487-506.

Čihák, M., Demirgüč-Kunt, A., Feyen, E., \& Levine, R. (2013). Financial development in 205 economies, 1960 to 2010. https:/ / doi.org/10.3386/w18946

Claessens, S., \& Laeven, L. (2005). Financial dependence, banking sector competition, and economic growth. Journal of the European Economic Association, 3(1), 179-207. https:// doi.org/10.1162/1542476053295322

Clark, E., Radić, N., \& Sharipova, A. (2018). Bank competition and stability in the CIS markets. Journal of International Financial Markets, Institutions and Money, 54, 190-203. https:// doi.org/10.1016/j.intfin.2017.12.005

Cocco, J. F., Gomes, F. J., \& Martins, N. C. (2009). Lending relationships in the interbank market. Journal of Financial Intermediation, 18(1), 24-48. https:// doi.org/10.1016/j.jfi.2008.06.003

Dahir, A. M., Mahat, F. B., \& Ali, N. A. Bin. (2018). Funding liquidity risk and bank risktaking in BRICS countries: An application of system GMM approach. International Journal of Emerging Markets, 13(1), 231-248. https:// doi.org/10.1108/IJoEM-03-20170086

Fahrial, F. (2018). Peranan bank dalam pembangunan ekonomi nasional. Ensiklopedia of Journal, 1(1). https:/ / doi.org/10.33559/EOJ.V1I1.54

Gutiérrez de Rozas, L. (2011). Testing for competition in the Spanish banking industry: The Panzar-Rosse approach revisited. SSRN Electronic Journal. https:// doi.org/10.2139/ssrn.1005116

Hellmann, T. F., Murdock, K. C., \& Stiglitz, J. E. (2000). Liberalization, moral hazard in banking, and prudential regulation: Are capital requirements enough? American Economic Review, 90(1), 147-165. https:/ / doi.org/10.1257/ aer.90.1.147

Jensen, M. C., \& Meckling, W. H. (1976). Theory of the firm: Managerial behavior, agency costs and ownership structure. Journal of Financial Economics, 3(4), 305-360. https:// doi.org/10.1016/0304-405X(76)90026-X

Jumono, S., Abdurrahman, A., \& Mala, C. M. F. (2017). Market concentration index and performance: Evidence from Indonesian banking industry. International Journal of Economics and Financial Issues, 7(2), 249-258.

Khan, M. S., Scheule, H., \& Wu, E. (2017). Funding liquidity and bank risk taking. Journal of Banking \& Finance, 82, 203-216. https:/ / doi.org/10.1016/j.jbankfin.2016.09.005

King, M. R. (2013). The Basel III net stable funding ratio and bank net interest margins. Journal of Banking and Finance, 37(11), 4144-4156. https:// doi.org/10.1016/j.jbankfin.2013.07.017 
Kroszner, R., Laeven, L., \& Klingebiel, D. (2007). Banking crises, financial dependence, and growth. Journal of Financial Economics, 84(1), 187-228. https:// doi.org/10.1016/j.jfineco.2006.05.001

Ly, K. C., Chen, Z., Wang, S., \& Jiang, Y. (2017). The Basel III net stable funding ratio adjustment speed and systemic risk. Research in International Business and Finance, 39, 169-182. https:/ / doi.org/10.1016/j.ribaf.2016.07.031

Nguyen, M., Perera, S., \& Skully, M. (2017). Bank market power, asset liquidity and funding liquidity: International evidence. International Review of Financial Analysis, 54, 23-38. https:// doi.org/10.1016/j.irfa.2017.09.002

OECD. (2011). Competition issues in the financial sector. https://www.oecd.org/daf/competition/sectors/competitionissuesinthefinancialse ctor-2011.htm

Otoritas Jasa Keuangan. (2017). Peraturan Otoritas Jasa Keuangan nomor 50/POJK.03/2017 tentang kewajiban pemenuhan rasio pendanaan stabil bersih (net stable funding ratio) bagi bank umum. https://www.ojk.go.id/id/kanal/perbankan/regulasi/peraturanojk/Documents/Pages/POJK-tentang-Kewajiban-Pemenuhan-Rasio-PendanaanStabil-Bersih-(Net-Stable-Funding-Ratio)-bagi-Bank-Umum/SAL POJK $50 \quad-$ NSFR.pdf

Pricillia, N. (2015). The risk-taking behaviour of Indonesian banks using SCP paradigm. Bina Ekonomi, 19(2), 91-103. https:/ / doi.org/10.26593/ be.v19i2.1481.91-104

Saunders, A., \& Cornett, M. M. (2017). Financial institutions management: A risk management approach. McGraw-Hill Education.

Van Leuvensteijn, M., Sørensen, K., Bikker, J. A., \& Van Rixtel, A. A. R. J. M. (2008). Impact of bank competition on the interest rate pass-through in the euro area. http:/ / ssrn.com/abstract_id=1105385.

Wang, X., Zeng, X., \& Zhang, Z. (2014). The influence of the market power of Chinese commercial banks on efficiency and stability. China Finance Review International, 4(4), 307-325. https:// doi.org/10.1108/CFRI-07-2013-0096

World Bank. (2020). The World Bank In Indonesia. https://www.worldbank.org/en/country/indonesia/overview

Wu, J., Guo, M., Chen, M., \& Jeon, B. N. (2019). Market power and risk-taking of banks: Some semiparametric evidence from emerging economies. Emerging Markets Review, 41, 100630. https:// doi.org/10.1016/j.ememar.2019.100630

Yuanita, N. (2019). Competition and bank profitability. Journal of Economic Structures, 8(1), 31. https://doi.org/10.1186/s40008-019-0164-0 